\title{
The profibrotic effect of downregulated Na,K-ATPase $\beta 1$ subunit in alveolar epithelial cells during lung fibrosis
}

\author{
BIYUN LI ${ }^{1}$, XIAOXI HUANG ${ }^{2}$, XUEFENG XU ${ }^{3}$, WEN NING ${ }^{4}$, HUAPING DAI ${ }^{1,5}$ and CHEN WANG ${ }^{1,5}$ \\ ${ }^{1}$ Department of Pulmonary and Critical Care Medicine, China-Japan Friendship School of Clinical Medicine, \\ Peking University, Beijing 100029; ${ }^{2}$ Department of Medical Research, Beijing Chao-Yang Hospital, Beijing 100020; \\ ${ }^{3}$ Department of Surgical Intensive Care Unit, Beijing An-Zhen Hospital, Capital Medical University, Beijing 100029; \\ ${ }^{4}$ Department of Genetics and Cellular Biology, College of Life Sciences, Nankai University, Tianjin 300071; \\ ${ }^{5}$ Department of Pulmonary and Critical Care Medicine, Center of Respiratory Medicine, China-Japan Friendship Hospital, \\ National Clinical Research Center for Respiratory Diseases, Peking University Health Science Center, \\ Beijing 100029, P.R. China
}

Received November 20, 2018; Accepted April 8, 2019

DOI: $10.3892 / \mathrm{ijmm} .2019 .4201$

\begin{abstract}
Abtract. Idiopathic pulmonary fibrosis (IPF) is a chronic progressive interstitial lung disease characterized by progressive lung scarring and excessive extracellular matrix depositon. When stimulated, alveolar epithelial cells (AECs) are aberrantly activated, the expression of profibrotic molecules is enhanced, and lung fibrosis is promoted, but the mechanism for this is unclear. It has been reported that a downregulation of the Na,K-ATPase $\beta 1$ subunit in renal epithelial cells is involved in renal fibrosis development, but the role of this protein in lung fibrosis remains unknown. In the present study, the expression of the Na,K-ATPase $\beta 1$ subunit was revealed to be markedly decreased in AECs of patients with IPF and a bleomycin-induced pulmonary fibrosis mouse model. Treatment with transforming growth factor $\beta-1$ led to significantly downregulation of the Na,K-ATPase $\beta 1$ subunit in lung adenocarcioma A549 cells. Furthermore, the knockdown of the Na,K-ATPase $\beta 1$ subunit in A549 cells resulted in the upregulation of profibrotic molecules, activation of the neurogenic locus notch homolog protein 1 and extracellular signal-regulated kinase $1 / 2$ signaling pathways and induction of endoplasmic reticulum stress. These findings reveal that the downregulation of the $\mathrm{Na}, \mathrm{K}$-ATPase $\beta 1$ subunit enhances
\end{abstract}

Correspondence to: Dr Chen Wang or Dr Huaping Dai, Department of Pulmonary and Critical Care Medicine, Center of Respiratory Medicine, China-Japan Friendship Hospital, National Clinical Research Center for Respiratory Diseases, Peking University Health Science Center, 2 Yinghuayuan Dongjie, Beijing 100029, P.R. China E-mail: cyh-birm@263.net

E-mail: daihuaping@ccmu.edu.cn

Key words: Na,K-ATPase $\beta 1$ subunit, alveolar epithelial cells, profibrotic proteins, idiopathic pulmonary fibrosis the expression of profibrotic molecules in AECs and may contribute to IPF pathogenesis.

\section{Introduction}

Idiopathic pulmonary fibrosis (IPF) is a prevalent and progressive fatal fibrotic lung disease with few available effective therapies (1-4). It mainly occurs in elderly adults with a median survival time of 2-3 years $(5,6)$, and the etiology of IPF remains unclear. A prevailing hypothesis for IPF pathogenesis is that abnormal wound healing in response to ongoing alveolar epithelial microinjuries causes fibroblast activation and excess extracellular matrix deposition, ultimately resulting in lung damage (7-9).

Alveolar epithelial cells (AECs) serve a crucial role in IPF pathogenesis (10). Persistent microinjuries to AECs are thought to be a trigger of lung fibrosis. The origins of lung injury are often varied and complex. Exposure to smoke, various types of dust, gastroesophageal reflux and viral infection can induce AEC injury (11-15). Rebuilding AECs is a key component of normal wound healing following injury. This requires a carefully programmed response, including the proliferation and migration of type II AECs. However, type II AECs isolated from the lungs of patients with IPF are aberrantly activated with increased collagen, $\alpha$-smooth muscle actin ( $\alpha$-SMA) and fibronectin, and decreased expression of E-cadherin (16). The role of epithelial-mesenchymal transition (EMT) in lung fibrosis remains controversial (17,18). Furthermore, AEC senescence, endoplasmic reticulum (ER) stress, fibroblast resistance to apoptosis, insufficient autophagy, ubiquitination dysfuction, abnormal macrophage activation, gene mutation and epigenetic changes are involved in IPF development (19-25).

The Na,K-ATPase $\beta 1$ subunit has been reported to be involved in organ fibrosis. Rajasekaran et al (26) demonstrated that $\mathrm{Na}, \mathrm{K}-\mathrm{ATPase} \beta 1$ subunit expression is significantly decreased in renal fibrotic tissues. The knockdown of this subunit in porcine kidney LLC-PK1 cells induced EMT, as did its downregulation in retinal pigment epithelial cells (27). 
$\mathrm{Na}, \mathrm{K}-\mathrm{ATP}$ ase, also known as a sodium pump, transports $3 \mathrm{Na}^{+}$ and $2 \mathrm{~K}^{+}$ions in opposite directions across the cell membrane to maintain osmotic equilibrium. This protein pump is composed of 3 subunits, $\alpha, \beta$ and $\gamma$. The functional $\alpha$ subunit has 4 isoforms ( $\alpha 1, \alpha 2, \alpha 3$ and $\alpha 4)$, whereas the $\beta$ ( $\beta 1, \beta 2$ and $\beta 3$ ) and $\gamma$ (isoforms 1-7) subunits are regulatory (28). Additional functions of Na,K-ATPase have been identified in the regulation of cell proliferation, cell motility, and apoptosis $(29,30)$.

In the present study, the expression of Na,K-ATPase $\beta 1$ subunit was revealed to be decreased in AECs of patients with IPF and in a bleomycin-induced pulmonary fibrosis mouse model. Based on this observation, the role of the downregulation of the Na,K-ATPase $\beta 1$ subunit in AECs during lung fibrosis was investigated.

\section{Materials and methods}

Tissue samples form patients. Lung tissue samples from 13 patients with IPF and 5 healthy donors (all male; age $51.08 \pm 10.03$ years) were obtained from the China-Japan Friendship Hospital (Beijing, China) during surgical lung biopsy and lung transplantation for inclusion in the present study. The diagnosis of IPF was based on the 2011 American Thoracic Society/European Respiratory Society/Japanese Respiratory Society/Latin American Thoracic Association Guidelines for Diagnosis and Management (5). All patients provided signed consent and the study was approved by the Ethics Committee of the China-Japan Friendship Hospital (approval no. 2017-25-1).

Animal model. C57BL/6N mice (50 mice; male; 7-8 weeks old; 22-24 g) were purchased from Beijing Vital River Laboratory Animal Technology Co., Ltd. (Beijing, China). The animals were maintained at a controlled temperature of $24 \pm 1^{\circ} \mathrm{C}$ with a $12 / 12 \mathrm{~h}$ light-dark cycle, and were fed a standard diet. Water was freely available. The mice were randomly divided into 2 groups: For the model of pulmonary fibrosis, a dose of $2 \mathrm{mg} / \mathrm{kg}$ bleomycin (Nippon Kayaku Co., Ltd., Tokyo, Japan) was intratracheally administered, and the control mice were injected intratracheally with the same volume of saline. The bleomycin and saline were adminstrated only once. The mice were euthanized on day 21 with an intraperitoneal injection of $1 \%$ pentobarbital sodium (100 mg/kg animal weight). This study was approved by the Animal Ethics Committee of China-Japan Friendship Hospital (Beijing, China).

Immunohistochemistry and immunofluorescence. The preparation of the human and mouse lung specimens for histology was performed as previously described $(23,31)$. Briefly, the samples were dehydrated, paraffin-embedded, and cut into $4-\mu \mathrm{m}$ sections. The tissue sections were deparaffinized and rehydrated. Following a microwave treatment for $20 \mathrm{~min}$ in EDTA buffer and subsequent cooling, the endogenous peroxidase activity was blocked with $0.3 \%$ hydrogen peroxide in methanol for $15 \mathrm{~min}$ in the dark. Following blocking in 5\% goat serum (OriGene Technologies, Inc., Beijing, China) for $20 \mathrm{~min}$, the sections were incubated with antibodies against the Na,K-ATPase $\beta 1$ subunit (cat. no. ab193669; 1:600 dilution) and fibronectin (cat. no. ab2413; 1:500 dilution) (both Abcam, Cambridge, UK) overnight at $4^{\circ} \mathrm{C}$ as described previously (32), the samples were observed using an optical microscope (magnification, x100) and were analyzed using Aperio Imagescope version 12.0 software (Leica Microsystems, Ltd., Milton Keynes, UK).

For immunofluorescence, the mouse lung tissue sections $(4 \mu \mathrm{m})$ were de-paraffinized, hydrated using xylene, 100 , 95, 85 and $70 \%$ ethanol, and PBS solution. The non-specific binding was blocked with $10 \%$ goat serum, and the samples were incubated overnight at $4^{\circ} \mathrm{C}$ with the desired primary antibodies against the Na,K-ATPase $\beta 1$ subunit (cat. no. ab2873; 1:500 dilution) and prosurfactant protein $\mathrm{C}$ (cat. no. ab90716; 1:4,000 dilution) (both Abcam), and then incubated with a specific fluorescence-conjugated secondary IgG (fluorescein isothiocyanate-conjugated, cat. no. ZF-0311; rhodamine B isothiocyanate-conjugated, cat. no. ZF-0313; both 1:100 dilution; OriGene Technologies, Inc.) for $1 \mathrm{~h}$ in a light-protected chamber at room temperature. Subsequently, the sections were counterstained with DAPI (cat. no. P0131; Beyotime Institute of Biotechnology, Haimen, China) at room temperature and immunofluorescence signals were detected immediately using fluorescence microscopy (magnification, x100).

Cell culture and small interfering (si)RNA transfection. Human lung carcinoma epithelial A549 cells were purchased from the American Type Culture Collection (Manassas, VA, USA). A549 is a human AEC line with similar characteristics to type II AECs. It has been used as a stable AEC line in a number of studies $(33,34)$. The cells were maintained in RPMI-1640 medium with $10 \%$ fetal bovine serum (both Gibco; Thermo Fisher Scientific, Inc., Waltham, MA, USA), 100 U/ml penicillin and $100 \mathrm{mg} / \mathrm{ml}$ streptomycin (both Hyclone; GE Healthcare Life Sciences, Logan, UT, USA). Transforming growth factor $\beta-1$ (TGF- $\beta 1 ; 10 \mathrm{ng} / \mathrm{ml}$; R\&D Systems, Inc., Minneapolis, MN, USA) was added to subconfluent cultures and the same volume of citric acid was added to the control cells. The cells were maintained in a humidified incubator at $37^{\circ} \mathrm{C}$ in $95 \%$ air $\left(21 \% \mathrm{O}_{2}\right)$ and $5 \% \mathrm{CO}_{2}$.

The A549 cells were seeded in 6-well plates and incubated overnight. Na,K-ATPase $\beta 1$ subunit siRNA ( $5 \mu \mathrm{M}$; sequence, 5'-AAUGUUCUCACCGUACGCCtt- 3 ') and negative control siRNA (5 $\mu$ M; cat. no. 4390843; Silencer ${ }^{\circledR}$ Select Negative Control; Thermo Fisher Scientific, Inc.) were separately mixed with Lipofectamine ${ }^{\circledR} 3000$ transfection reagent (Invitrogen; Thermo Fisher Scientific, Inc.) and Opti-MEM medium (Thermo Fisher Scientific, Inc.) according to the manufacturer's instructions. The cells were incubated for $24 \mathrm{~h}$ for the measurement of RNA levels and $48 \mathrm{~h}$ for cell morphology observation under an optical microscope and protein detection experiments.

$R N A$ purification and reverse transcription-quantitative polymerase chain reaction ( $R T-q P C R)$ analysis. As previously described (35), total RNA was isolated from the cells using TRIzol reagent (Invitrogen; Thermo Fisher Scientific, Inc.) according to the manufacturer's instructions. RT was performed on $1 \mu \mathrm{g}$ total RNA with oligo(dT) primers in $25-\mu \mathrm{l}$ reactions using the Omniscript RT kit (Tiangen Biotech Co., Ltd., Beijing, China) at $37^{\circ} \mathrm{C}$ for $60 \mathrm{~min}$ according to the manufacturer's instructions. The qPCR was performed on an ABI 7500 instrument (Applied Biosystems; Thermo Fisher 
Scientific, Inc.) using SYBR-Green PCR reagents (Tiangen Biotech Co., Ltd.). The thermocycling conditions used were as follows: Initial denaturation at $94^{\circ} \mathrm{C}$ for $2 \mathrm{~min}$ and 40 cycles of denaturation at $94^{\circ} \mathrm{C}$ for $15 \mathrm{sec}$, annealing at $55^{\circ} \mathrm{C}$ for $20 \mathrm{sec}$ and extension at $69^{\circ} \mathrm{C}$ for $35 \mathrm{sec}$. The primers used were: $\beta$-actin forward, 5'-AGGCCAACCGTGAAAAGATG-3'; and reverse, 5'-AGAGCATAGCCCTCGTAGATGG-3'; and Na,K-ATPase $\beta 1$ subunit forward, 5'-ATGTGCCCAGTGAACCGAAA-3'; and reverse, 5'-TCCAGAGCAATTTCCCAGCC-3'. The relative expression of the target gene was calculated using the $2^{-\Delta \Delta \mathrm{Cq}}$ method (36), normalized to the levels of $\beta$-actin.

Protein extraction and western blot analysis. Total cell lysates were obtained using radioimmunoprecipitation assay buffer (Beijing Solarbio Science \& Technology Co., Ltd., Beijing, China) containing 1:100 phenylmethylsulfonyl fluoride, phosphatase inhibitors and protease inhibitor. The cell lysates were resuspended in protein loading buffer containing 5\% mercaptoethanol. The protein concentration was determined using a bicinchoninic acid assay kit. Western blotting was performed as previously described (23). The denatured proteins ( $20 \mu \mathrm{g}$ per lane) were separated by $10 \%$ SDS-PAGE using a Mini-Protein electrophoresis module assembly (both Bio-Rad Laboratories, Inc., Hercules, CA, USA) at $80 \mathrm{mV}$ and transferred to nitrocellulose membranes (Merck KGaA, Darmstadt, Germany) for 100-120 min using the Mini Trans-Blot electrophoresis transfer cell (Bio-Rad Laboratories, Inc.) at $300 \mathrm{~mA}$, according to the molecular weight. The primary antibodies used were anti-human and mouse $\alpha$-SMA (cat. no. ab124964; 1:5,000 dilution), fibronectin (cat. no. ab2413; 1:2,000 dilution), $\beta$-actin (cat. no. ab6267; 1:3,000 dilution), Na,K-ATPase $\beta 1$ subunit (cat. no. ab2873; 1:600 dilution) (all Abcam), cleaved Notch1 (cat. no. 4147T), extracellular signal-regulated kinase (ERK)1/2 (cat. no. 9101), phosphorylated ERK1/2 (cat. no. 8544), and immunoglobulin heavy chain-binding protein (BiP, cat. no. 3177T) (all 1:1,000 dilution; Cell Signaling Technology, Inc., Danvers, MA, USA). The membranes were incubated with the primary antibodies overnight at $4{ }^{\circ} \mathrm{C}$ and treated with IRDyeCW800 (green)- or IRDyeCW800 (red)-conjugated affinity purified anti-rabbit (cat. no. 925-32211) or anti-mouse (cat. no. 925-32210) IgG (both 1:15,000 dilution; LI-COR Biosciences, Lincoln, NE, USA). The intensity of the bands was evaluated using a LI-COR Odyssey infrared double-fluorescence imaging system (LI-COR Image Studio Software version 4.0; LI-COR Biosciences).

Statistical analysis. Data are expressed as mean \pm standard error of the mean. Two-tailed Student's t-test was performed for the comparison of mRNA and protein expression levels. The statistical analyses were performed using the Prism software version 5.0 (GraphPad Software, Inc., La Jolla, CA, USA). $\mathrm{P}<0.05$ was considered to indicate statistically significant differences.

\section{Results}

Na,K-ATPase $\beta 1$ subunit expression is downregulated in lung fibrosis. To examine the Na,K-ATPase $\beta 1$ subunit expression level in lung fibrosis, immunohistochemistry was performed on lung tissue sections from patients with IPF. The Na,K-ATPase $\beta 1$ subunit was mainly expressed in the cytoplasm of AECs. The staining of this subunit was visibly diminished in the fibrotic and lesion-adjacent areas compared with that in the healthy lung tissue (Fig. 1A). Na,K-ATPase $\beta 1$ subunit expression was also investigated in tissue from a bleomycin-induced pulmonary fibrosis mouse model. The results of the western blot and immunohistochemistry analyses demonstrated that $\mathrm{Na}, \mathrm{K}-\mathrm{ATPase} \beta 1$ subunit expression was markedly decreased in the lung tissue of the bleomycin group compared with that of control (Fig. 1B and C).

Na,K-ATPase $\beta 1$ subunit expression in type II AECs in mouse lung tissue. In contrast to the human lung tissue, the immunohistochemistry of the mouse lung tissue revealed that not all AECs express the Na,K-ATPase $\beta 1$ subunit (Fig. 1B). Therefore, immunofluorescence was used to identify which type of AECs express $\mathrm{Na}, \mathrm{K}$-ATPase $\beta 1$ subunit in mouse lung. As displayed in Fig. 2, the Na,K-ATPase $\beta 1$ subunit was primarily expressed in the cell membrane of type II AECs.

TGF- $\beta 1$ treatment decreases Na,K-ATPase $\beta 1$ subunit expression in A549 cells. TGF- $\beta 1$ is an important profibrotic cytokine. To assess the level of Na,K-ATPase $\beta 1$ subunit in TGF- $\beta 1$-stimulated AECs, total protein was extracted from the cells following treatment with $10 \mathrm{ng} / \mathrm{ml}$ TGF- $\beta 1$ for 48 and $72 \mathrm{~h}$. The results indicated that the treatment led to a significant decrease in the protein expression of Na,K-ATPase $\beta 1$ subunit at the two tested time points (Fig. 3).

Knockdown of Na,K-ATPase $\beta 1$ subunit mediates changes in the cell morphology of A549 cells. Due to the observed significant difference between the expression of Na,K-ATPase $\beta 1$ subunit in lung fibrosis and normal lung samples, the effects of the downregulation of the $\mathrm{Na}, \mathrm{K}$-ATPase $\beta 1$ subunit on AECs was explored. The Na,K-ATPase $\beta 1$ subunit expression in A549 cells was knocked down using siRNA interference. As demonstrated in Fig. 4A, Na,K-ATPase $\beta 1$ subunit mRNA was significantly decreased $24 \mathrm{~h}$ post-transfection, as were the protein expression levels at $48 \mathrm{~h}$ (Fig. 4B and C). In addition, the knockdown of $\mathrm{Na}, \mathrm{K}-\mathrm{ATPase} \beta 1$ subunit resulted in an altered spindle morphology in the A549 cells (Fig. 4D).

Knockdown of the Na,K-ATPase $\beta 1$ subunit promotes the upregulation of profibrotic proteins in A549 cells. To further investigate the role of the $\mathrm{Na}, \mathrm{K}$-ATPase $\beta 1$ subunit in AECs during lung fibrosis, the expression of fibrosis-associated proteins fibronectin, $\alpha$-SMA and E-cadherin was examined in A549 cells following siRNA silencing of the Na,K-ATPase $\beta 1$ subunit. The results revealed that the fibronectin and $\alpha$-SMA levels were increased, but E-cadherin expression was not significantly altered, compared with that in the cells transfected with NC-siRNA (Fig. 5).

Knockdown of the Na,K-ATPase $\beta 1$ subunit activates ERK $1 / 2$ and neurogenic locus notch homolog protein 1 (Notch1) signaling and induces ER stress. The downstream signaling pathway of the Na,K-ATPase $\beta 1$ subunit was investigated. As observed in Fig. 6A, phosphorylated ERK1/2 and cleaved Notch1 were significantly upregulated in cells with 
A

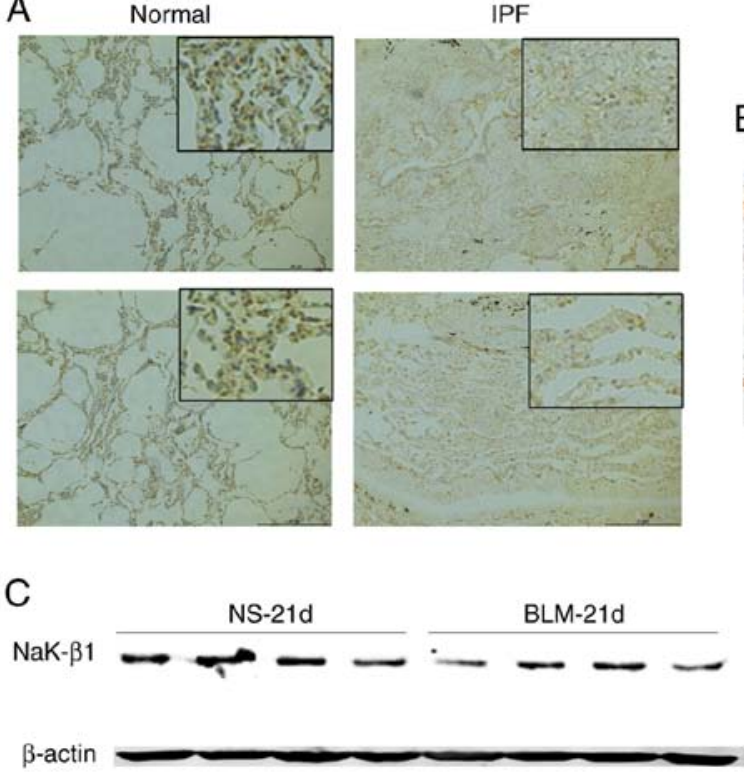

B
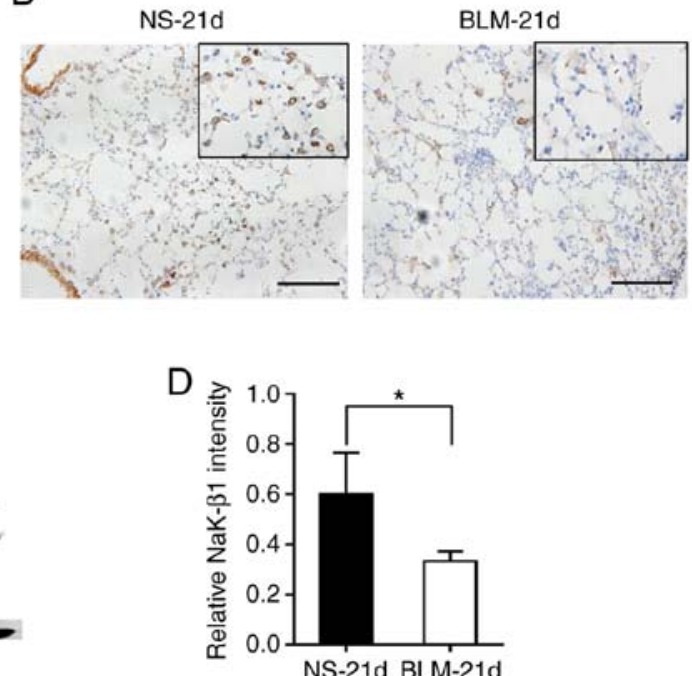

Figure 1. NaK- $\beta 1$ expression in lung fibrosis. (A) Representative immunohistochemistry images of NaK- $\beta 1$ staining in lung tissue sections from patients with IPF. Original magnification, $\mathrm{x} 100$; scale bar, $20 \mu \mathrm{m}$. (B) Representative immunohistochemistry of NaK- $\beta 1$ staining in lung tissue samples from a bleomycin-induced pulmonary fibrosis mouse model. Original magnification, 100x; scale bar, $10 \mu \mathrm{m}$; upper right panel scale bar, $1 \mu \mathrm{m}$. (C) Western blot analysis of protein extracted from lung tissue of a BLM-induced pulmonary fibrosis mouse model. (D) Relative quantification of the western blot band intensities. Data are expressed as the mean \pm standard error of the mean ( $n=4$ mice per group). ${ }^{*} \mathrm{P}<0.05$. IPF, idiopathic pulmonary fibrosis; NaK- $\beta 1, \mathrm{Na}, \mathrm{K}-\mathrm{ATPase} \beta 1$ subunit; NS, saline-administered control group; BLM, bleomycin.

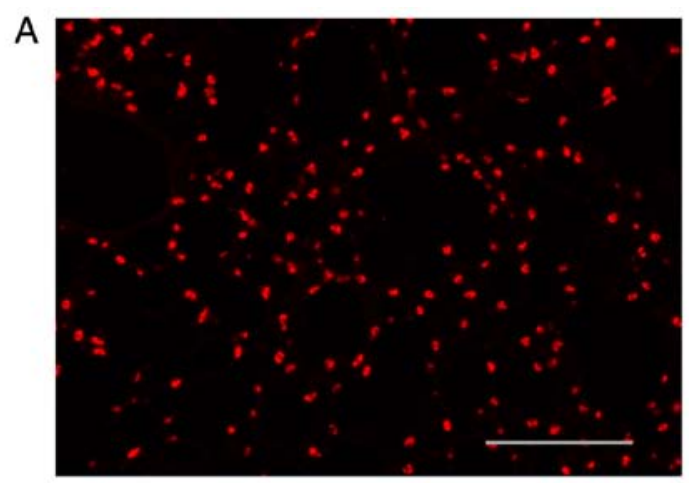

SPC

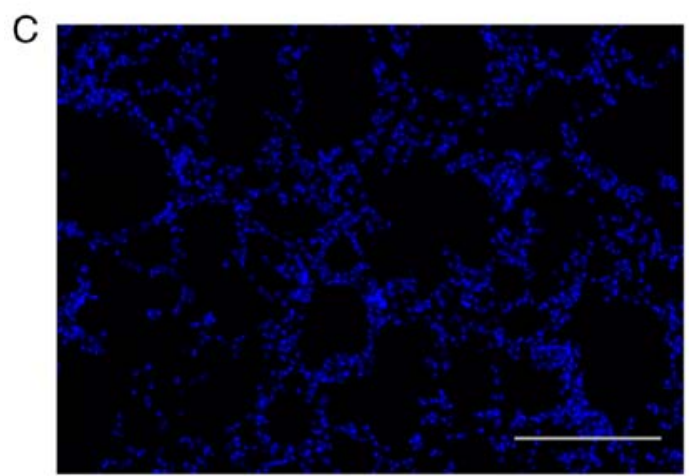

DAPI

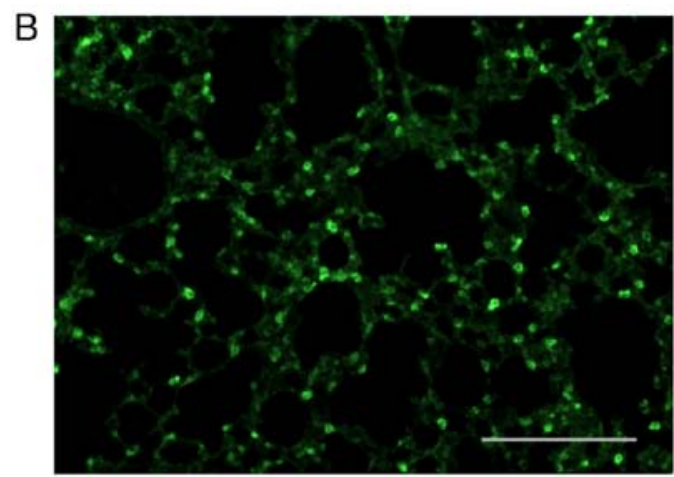

NaK- $\beta 1$

$\mathrm{D}$

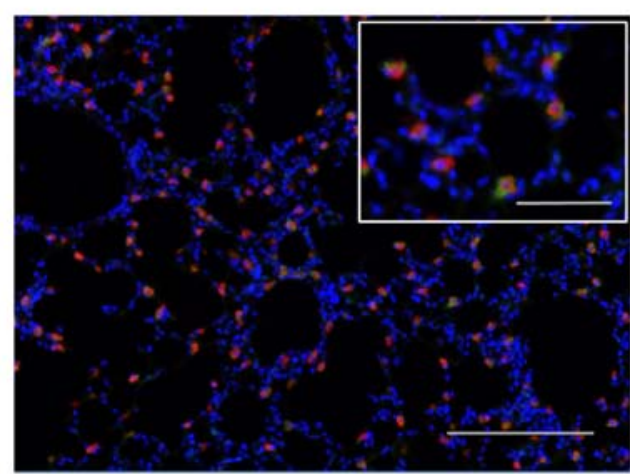

SPC+NaK-B1+DAPI

Figure 2. NaK- $\beta 1$ expression in type II AECs in mouse lung tissues. Representative immunofluorescence images of (A) SPC (red), (B) NaK- $\beta 1$ (green) and (C) nuclei (blue) in mouse lung tissue. (D) Merged image of the three types of staining. Original magnification, x100; scale bar, $10 \mu \mathrm{m}$; upper right panel scale bar, $1 \mu \mathrm{m}$. NaK- $\beta 1$, Na,K-ATPase $\beta 1$ subunit; SPC, surface protein C.

$\mathrm{Na}, \mathrm{K}-\mathrm{ATPa}$ e $\beta 1$ subunit silencing, suggesting that a deficiency of this protein may lead to the activation of the ERK1/2 and
Notch1 signaling pathways, contributing to lung fibrosis. In addition, the knockdown of Na,K-ATPase $\beta 1$ subunit resulted 
A

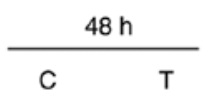

NaK- $\beta 1$
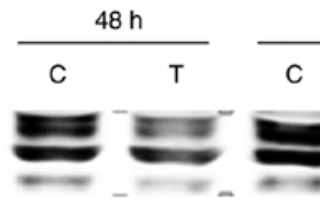

$72 \mathrm{~h}$

C $T$

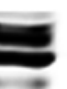

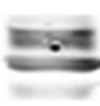

$\beta$-actin

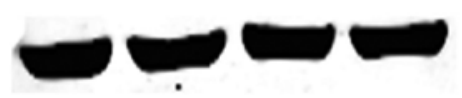

B

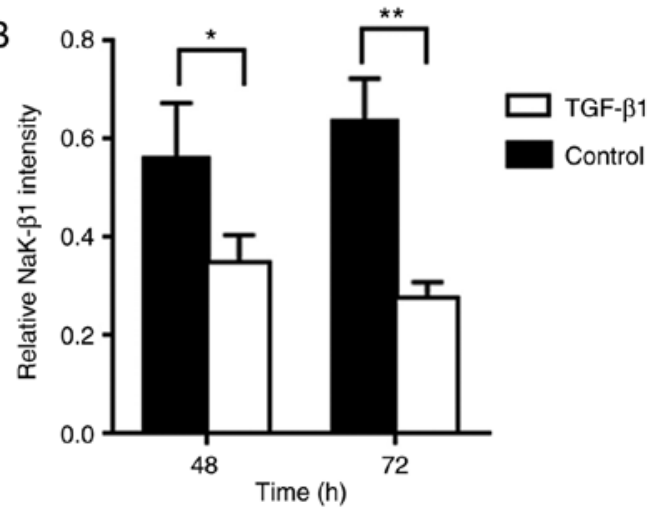

Figure 3. TGF- $\beta 1$ treatment decreases NaK- $\beta 1$ expression in A549 cells. (A) Representative image of a western blot analysis of NaK- $\beta 1$ from A549 cells treated with TGF- $\beta 1$ or citric acid for 48 or $72 \mathrm{~h}$. (B) Relative quantification of the western blotting results. The data are expressed as the mean \pm standard error of the mean. ${ }^{*} \mathrm{P}<0.05 ;{ }^{* *} \mathrm{P}<0.01$. NaK- $\beta 1, \mathrm{Na}, \mathrm{K}-\mathrm{ATPa}$ e $\beta 1$ subunit; TGF- $\beta 1$, transforming growth factor $\beta-1$.

B
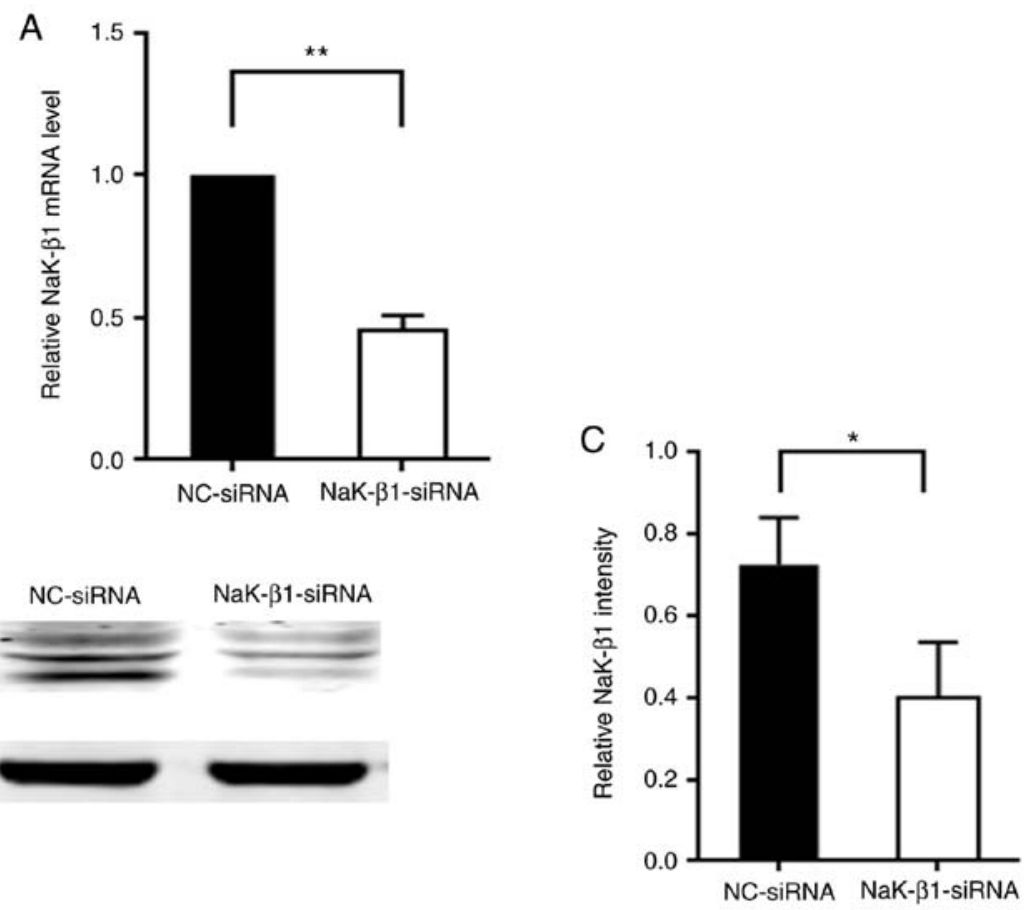

D
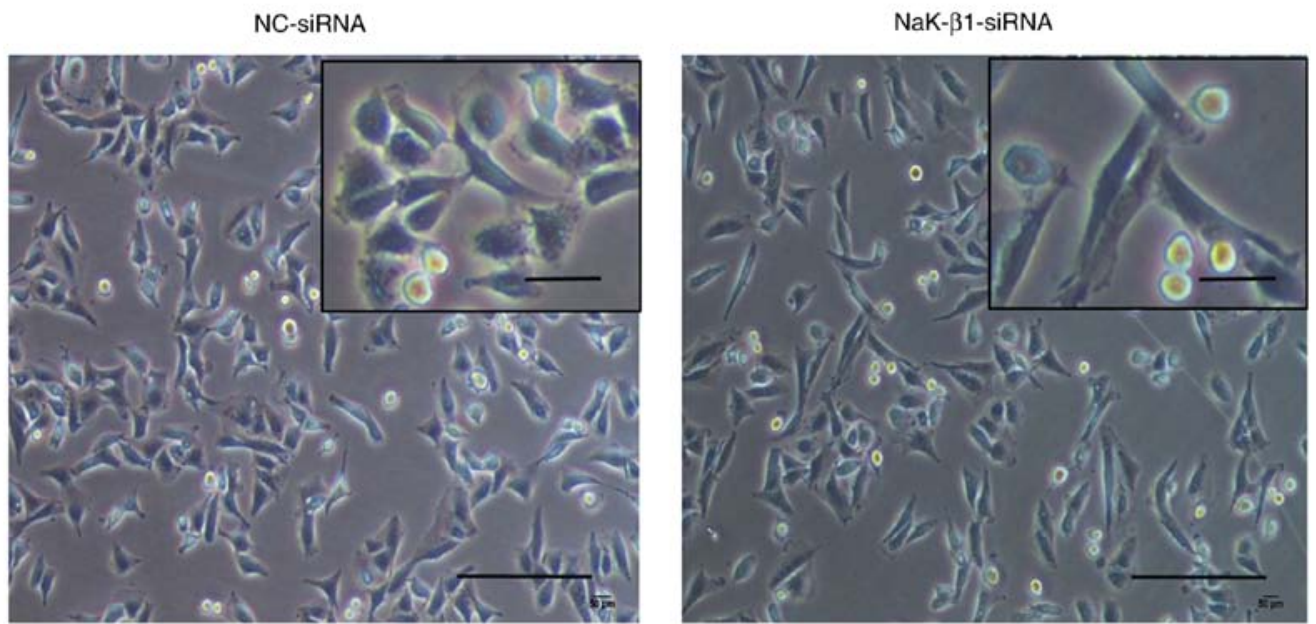

Figure 4. Knockdown of NaK- $\beta 1$ mediates spindle morphology changes in A549 cells. (A) Relative NaK- $\beta 1$ mRNA levels 24 h post-transfection with siRNA. (B) Western blot analysis of NaK- $\beta 1$ protein expression levels $48 \mathrm{~h}$ post-transfection. (C) Relative quantification of the western blotting results. The data are expressed as mean \pm standard error of the mean. ${ }^{*} \mathrm{P}<0.05 ;{ }^{* *} \mathrm{P}<0.01$. (D) Representative images indicating the morphology of A549 cells transfected with NaK- $\beta 1$ - and NC-siRNA for $48 \mathrm{~h}$. Original magnification, x20; scale bar, $50 \mu \mathrm{m}$; upper right panel scale bar, $5 \mu \mathrm{m}$. NaK- $\beta 1$, Na,K-ATPase $\beta 1$ subunit; $\mathrm{NC}$, negative control; siRNA, small interfering RNA. 

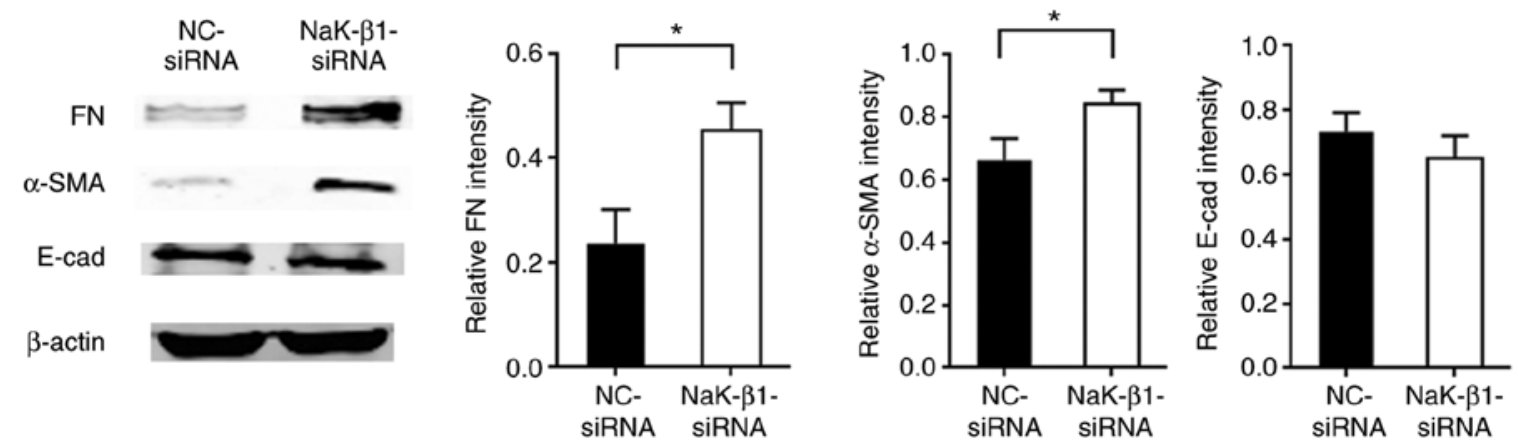

Figure 5. Knockdown of NaK- $\beta 1$ upregulates profibrotic proteins in A549 cells. Fibrosis-associated proteins FN, $\alpha$-SMA and E-cad expression levels were investigated $48 \mathrm{~h}$ after A549 cells were transfected with NaK- $\beta 1$ - and NC-siRNA, using western blot analysis. Representative western blot images and relative quantification of the results are indicated. The data are expressed as the mean \pm standard error of the mean. ${ }^{*} \mathrm{P}<0.05$. NaK- $\beta 1$, Na,K-ATPase $\beta 1$ subunit; FN, fibronectin; $\alpha$-SMA, $\alpha$-smooth muscle actin; E-cad, E-cadherin; NC, negative control; siRNA, small interfering RNA.
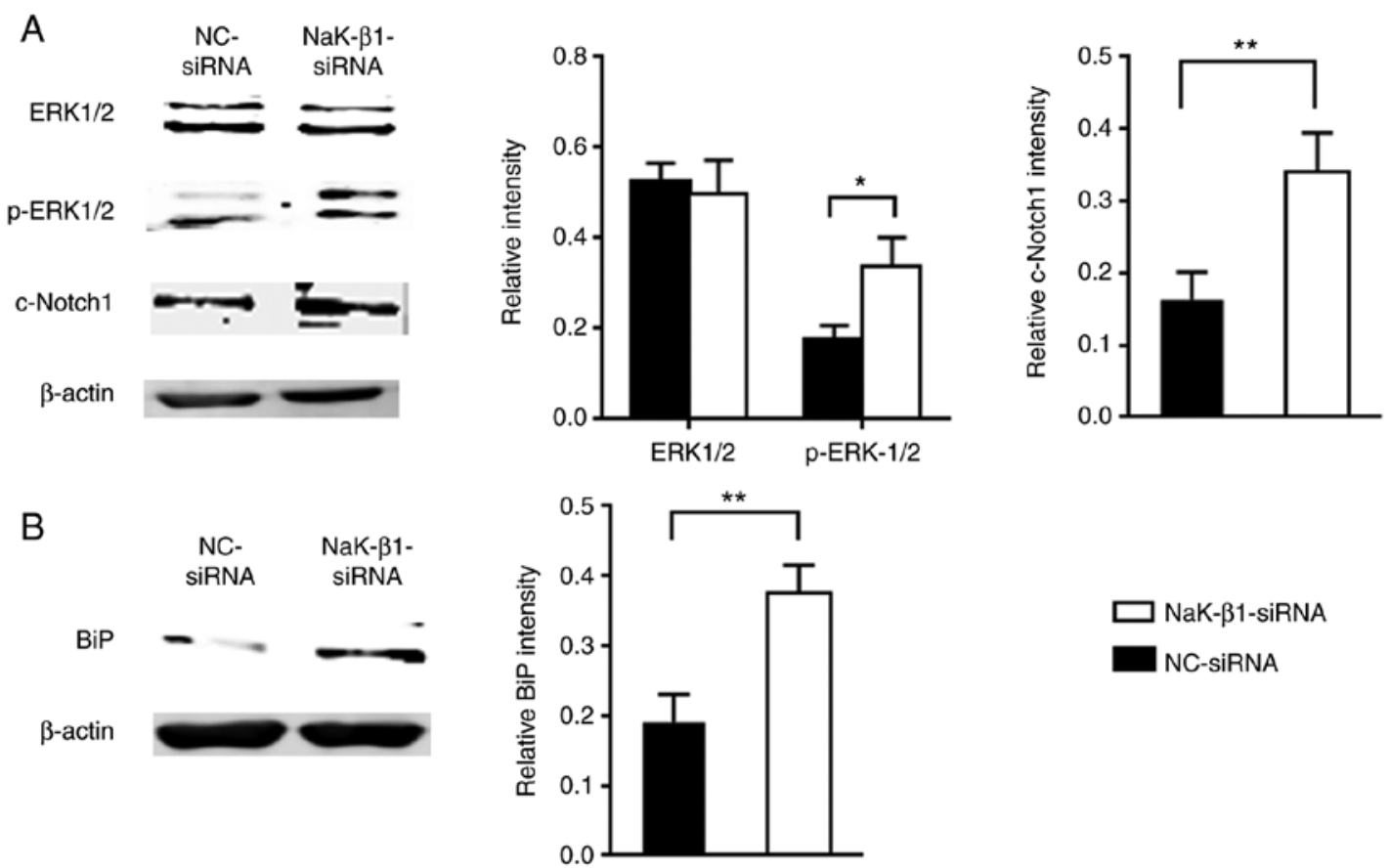

Figure 6. NaK- $\beta 1$ knockdown activates ERK1/2 and Notch1 signaling, inducing ER stress in A549 cells. Western blot analysis and relative quantification of (A) ERK1/2, p-ERK1/2 and cleaved Notch1 levels and (B) BiP levels in A549 cells transfected with NaK- $\beta 1$ - and NC-siRNA. The data are expressed as the mean \pm standard error of the mean. ${ }^{*} \mathrm{P}<0.05 ;{ }^{* * *} \mathrm{P}<0.01$. NaK- $\beta 1, \mathrm{Na}, \mathrm{K}-\mathrm{ATPase} \beta 1$ subunit; ERK, extracellular signal-regulated kinase; p-ERK1/2, phosphorylated ERK1/2; Notch1, neurogenic locus notch homolog protein 1; c-Notch1, cleaved Notch1; BiP, immunoglobulin heavy chain-binding protein; NC, negative control; siRNA, small interfering RNA.

in a significant increase in the expression of $\mathrm{BiP}$, an ER-stress protein marker (Fig. 6B), suggesting that downregulation of this ion pump causes ER stress in A549 cells.

\section{Discussion}

IPF is a chronic and lethal interstitial lung disease. It is generally accepted that the initial progression of IPF is stimulated by the aberrant activation of AECs in response to repetitive microinjury. In the present study, the Na,K-ATPase $\beta 1$ subunit protein expression was revealed to be downregulated in lung fibrosis, mainly in AECs, enhancing profibrotic protein expression, activating the ERK1/2 and Notch1 signaling pathways, and inducing ER stress, consequently leading to lung fibrosis.
The present study has demonstrated that the expression of the Na,K-ATPase $\beta 1$ subunit is different in human and mouse lung tissues. It is expressed in type I and II AECs, and located in the cytoplasm of AECs in human lungs. However, in mouse lungs, the $\mathrm{Na}, \mathrm{K}$-ATPase $\beta 1$ subunit is mainly expressed in type II AECs and is located in the cell membrane. The human $\mathrm{Na}, \mathrm{K}-\mathrm{ATP}$ ase $\beta 1$ subunit exhibits two bands in immunoblot analyses, where the lower 40-kDa band represents the intracellular immature fraction of the subunit and the higher molecular weight band represents the mature plasma membrane form. However, the mouse Na,K-ATPase $\beta 1$ subunit results in only a single 42-kDa band (37).

The Na,K-ATPase $\beta 1$ subunit belongs to the $\mathrm{N}$-linked glycoproteins, and as a regulatory subunit, its main fuction is to assist the folding of the $\alpha$ subunit and its transport from 
the ER to the plasma membrance (38). Furthermore, the $\mathrm{Na}, \mathrm{K}-\mathrm{ATPase} \beta 1$ subunit is a molecular partner of Wolframin, an ER protein involved in ER stress (39). The results of the present study indicated that the knockdown of this subunit led to the upregulation of BiP, whereas the level of DNA damage-inducible transcript 3 protein was not altered (data not shown). Over the past decades, accumulating evidence has suggested that ER stress serves an important role in the pathogenesis of lung fibrosis, as ER stress markers are highly expressed in AECs in IPF. ER stress in lung fibrosis induces AEC injury and apotosis, causing inflammation and cell phenotype alteration (20,40-43).

The present data revealed that the knockdown of $\mathrm{Na}, \mathrm{K}-\mathrm{ATPa}$ e $\beta 1$ subunit led to the enhanced expression of profibrotic proteins fibronectin and $\alpha$-SMA, but no changes in epithelial marker E-cadherin were observed, suggesting that AECs undergo incomplete activation and partly maintain epithelial characteristics (44). Treatment of A549 cells with TGF- $\beta 1$ resulted in a decrease in Na,K-ATPase $\beta 1$ subunit expression, which may affect electrolyte metabolism in AECs. Further investigation is required to clarify the role of $\mathrm{Na}, \mathrm{K}-\mathrm{ATPase} \alpha 1$ subunit-mediated electrolyte metabolism dysfuction in the pathegenesis of lung fibrosis.

Attempts to use plasmids to overexpress $\mathrm{Na}, \mathrm{K}$-ATPase $\beta 1$ subunit in A549 cells proved unsuccessful in the present study. Ouabain, an inhibitor of Na,K-ATPase, leads to the upregulation of $\mathrm{Na}, \mathrm{K}$-ATPase $\beta 1$ subunit expression and suppresses EMT $(26,45)$. In addition, a previous study of the present group revealed that ouabain ameliorates bleomycin-induced pulmonary fibrosis (46). Therefore, it can be inferred that this inhibitor suppresses EMT due to the upregulation of of $\mathrm{Na}, \mathrm{K}-\mathrm{ATPase} \beta 1$ subunit expression, providing direction of subsequent studies.

In conclusion, $\mathrm{Na}, \mathrm{K}-\mathrm{ATPase} \beta 1$ subunit expression is downregulated in clinical human IPF samples, in the lung tissue of a bleomycin-induced pulmonary fibrosis mouse model, and in TGF- $\beta 1$-stimulated lung carcinoma A549 cells. Additionally, Na,K-ATPase $\beta 1$ subunit deficiency in A549 cells upregulates profibrotic protein expression, activates ERK1/2 and Notch1 signaling pathways and induces ER stress. Therefore, the results of the present study suggest that decreased expression of $\mathrm{Na}, \mathrm{K}$-ATPase $\beta 1$ subunit in AECs serves a crucial role in the progression of lung fibrosis.

\section{Acknowledgements}

This abstract was presented at the ERS International Congress, September 15-19, 2018 in Paris, France and was published as Abstract no. PA3720 in the European Respiratory Journal 52 (Suppl 62) 2018. The authors thank Professor Ying Li, Department of Medical Research, Beijing Chao-Yang Hospital, Capital Medical University, Beijing, China, and Professor Yunchao Su, Department of Pharmacology and Toxicology, Charlie Norwood Veterans Affairs Medical Center, Augusta, GA, USA, for their excellent technical assistance.

\section{Funding}

This study was supported by grants from the National Natural Science Foundation of China (nos. 81430001 and 81470258).

\section{Availability of data and materials}

The datasets used and/or analyzed during the present study are available from the corresponding author on reasonable request.

\section{Authors' contributions}

BL, WN, HD and CW designed the experiments. BL performed the experiments and drafted the manuscript. BL, $\mathrm{XX}$ and $\mathrm{XH}$ analyzed the data. XX, WN, HD and CW revised the manuscript. All authors have read and approved the final version for publication.

\section{Ethics approval and consent to participate}

This study was approved by the Ethics Committee (approval no. 2017-25-1) and the Animal Ethics Committee (approval no. 2017-18-2) of China-Japan Friendship Hospital, Beijing, China.

\section{Patient consent for publication}

Not applicable.

\section{Competing interests}

The authors declare that they have no competing interests.

\section{References}

1. Coultas DB, Zumwalt RE, Black WC and Sobonya RE: The epidemiology of interstitial lung diseases. Am J Respir Crit Care Med 150: 967-972, 1994.

2. Mannino DM, Etzel RA and Parrish RG: Pulmonary fibrosis deaths in the United States, 1979-1991. An analysis of multiple-cause mortality data. Am J Respir Crit Care Med 153: 1548-1552, 1996.

3. Noble PW: Idiopathic pulmonary fibrosis: Natural history and prognosis. Clin Chest Med 27 (1 Suppl 1): S11-S16, v, 2006.

4. Raghu G, Weycker D, Edelsberg J, Bradford WZ and Oster G: Incidence and prevalence of idiopathic pulmonary fibrosis. Am J Respir Crit Care Med 174: 810-816, 2006.

5. Raghu G, Collard HR, Egan JJ, Martinez FJ, Behr J, Brown KK, Colby TV, Cordier JF, Flaherty KR, Lasky JA, et al: An official ATS/ERS/JRS/ALAT statement: Idiopathic pulmonary fibrosis: Evidence-based guidelines for diagnosis and management. Am J Respir Crit Care Med 183: 788-824, 2011.

6. Cai M, Zhu M, Ban C, Su J, Ye Q, Liu Y, Zhao W, Wang C and Dai H: Clinical features and outcomes of 210 patients with idiopathic pulmonary fibrosis. Chin Med J (Engl) 127: 1868-1873, 2014.

7. Selman M, King TE, Pardo A and American Thoracic Society; European Respiratory Society; American College of Chest Physicians: Idiopathic pulmonary fibrosis: Prevailing and evolving hypotheses about its pathogenesis and implications for therapy. Ann Intern Med 134: 136-151, 2001.

8. Thannickal VJ, Toews GB, White ES, Lynch JP III and Martinez FJ: Mechanisms of pulmonary fibrosis. Annu Rev Med 55: 395-417, 2004

9. Zoz DF, Lawson WE and Blackwell TS: Idiopathic pulmonary fibrosis: A disorder of epithelial cell dysfunction. Am J Med Sci 341: 435-438, 2011.

10. Selman M and Pardo A: Role of epithelial cells in idiopathic pulmonary fibrosis: From innocent targets to serial killers. Proc Am Thorac Soc 3: 364-372, 2006.

11. Baumgartner KB, Samet JM, Stidley CA, Colby TV and Waldron JA: Cigarette smoking: A risk factor for idiopathic pulmonary fibrosis. Am J Respir Crit Care Med 155: 242-248, 1997.

12. Taskar VS and Coultas DB: Is idiopathic pulmonary fibrosis an environmental disease? Proc Am Thorac Soc 3: 293-298, 2006. 
13. Raghu G, Freudenberger TD, Yang S, Curtis JR, Spada C, Hayes J, Sillery JK, Pope CE II and Pellegrini CA: High prevalence of abnormal acid gastro-oesophageal reflux in idiopathic pulmonary fibrosis. Eur Respir J 27: 136-142, 2006.

14. Hubbard R, Lewis S, Richards K, Johnston I and Britton J: Occupational exposure to metal or wood dust and aetiology of cryptogenic fibrosing alveolitis. Lancet 347: 284-289, 1996.

15. Kelly BG, Lok SS, Hasleton PS, Egan JJ and Stewart JP: A rearranged form of Epstein-Barr virus DNA is associated with idiopathic pulmonary fibrosis. Am J Respir Crit Care Med 166: $510-513,2002$.

16. Marmai C, Sutherland RE, Kim KK, Dolganov GM, Fang X, Kim SS, Jiang S, Golden JA, Hoopes CW, Matthay MA, et al: Alveolar epithelial cells express mesenchymal proteins in patients with idiopathic pulmonary fibrosis. Am J Physiol Lung Cell Mol Physiol 301: L71-L78, 2011.

17. Rock JR, Barkauskas CE, Cronce MJ, Xue Y, Harris JR, Liang J, Noble PW and Hogan BL: Multiple stromal populations contribute to pulmonary fibrosis without evidence for epithelial to mesenchymal transition. Proc Natl Acad Sci USA 108: E1475-E1483, 2011.

18. Kim KK, Kugler MC, Wolters PJ, Robillard L, Galvez MG, Brumwell AN, Sheppard D and Chapman HA: Alveolar epithelial cell mesenchymal transition develops in vivo during pulmonary fibrosis and is regulated by the extracellular matrix. Proc Natl Acad Sci USA 103: 13180-13185, 2006.

19. Jiang C, Liu G, Luckhardt T, Antony V, Zhou Y, Carter AB, Thannickal VJ and Liu RM: Serpine 1 induces alveolar type II cell senescence through activating p53-p21-Rb pathway in fibrotic lung disease. Aging Cell 16: 1114-1124, 2017.

20. Korfei M, Ruppert C, Mahavadi P, Henneke I, Markart P Koch M, Lang G, Fink L, Bohle RM, Seeger W, et al: Epithelial endoplasmic reticulum stress and apoptosis in sporadic idiopathic pulmonary fibrosis. Am J Respir Crit Care Med 178: 838-846, 2008.

21. Im J, Kim K, Hergert P and Nho RS: Idiopathic pulmonary fibrosis fibroblasts become resistant to Fas ligand-dependent apoptosis via the alteration of decoy receptor 3. J Pathol 240: 25-37, 2016

22. Araya J, Kojima J, Takasaka N, Ito S, Fujii S, Hara H, Yanagisawa H, Kobayashi K, Tsurushige C, Kawaishi M, et al: Insufficient autophagy in idiopathic pulmonary fibrosis. Am J Physiol Lung Cell Mol Physiol 304: L56-L69, 2013.

23. Geng J, Huang X, Li Y, Xu X, Li S, Jiang D, Liang J, Wang C and Dai H: Down-regulation of USP13 mediates phenotype transformation of fibroblasts in idiopathic pulmonary fibrosis. Respir Res 16: 124, 2015.

24. Nie Y, Sun L, Wu Y, Yang Y, Wang J, He H, Hu Y, Chang Y, Liang Q, Zhu J, et al: AKT2 regulates pulmonary inflammation and fibrosis via modulating macrophage activation. J Immunol 198: 4470-4480, 2017.

25. Peljto AL, Zhang Y, Fingerlin TE, Ma SF, Garcia JG, Richards TJ, Silveira LJ, Lindell KO, Steele MP, Loyd JE, et al: Association between the MUC5B promoter polymorphism and survival in patients with idiopathic pulmonary fibrosis. JAMA 309: 2232-2239, 2013

26. Rajasekaran SA, Huynh TP, Wolle DG, Espineda CE, Inge LJ, Skay A, Lassman C, Nicholas SB, Harper JF, Reeves AE, et al: $\mathrm{Na}, \mathrm{K}-\mathrm{ATPase}$ subunits as markers for epithelial-mesenchymal transition in cancer and fibrosis. Mol Cancer Ther 9: 1515-1524, 2010.

27. Mony S, Lee SJ, Harper JF, Barwe SP and Langhans SA: Regulation of Na,K-ATPase beta1-subunit in TGF- $\beta 2$-mediated epithelial-to-mesenchymal transition in human retinal pigmented epithelial cells. Exp Eye Res 115: 113-122, 2013

28. Pierre SV and Xie Z: The Na,K-ATPase receptor complex: Its organization and membership. Cell Biochem Biophys 46 : 303-316, 2006

29. Xie $\mathrm{Z}$ and Askari A: $\mathrm{Na}(+) / \mathrm{K}(+)-A T P a s e$ as a signal transducer. Eur J Biochem 269: 2434-2439, 2002
30. Barwe SP, Anilkumar G, Moon SY, Zheng Y, Whitelegge JP, Rajasekaran SA and Rajasekaran AK: Novel role for $\mathrm{Na}, \mathrm{K}$-ATPase in phosphatidylinositol 3-kinase signaling and suppression of cell motility. Mol Biol Cell 16: 1082-1094, 2005.

31. Dong Y, Geng Y, Li L, Li X, Yan X, Fang Y, Zheng X, Dong S, Liu X, Yang X, et al: Blocking follistatin-like 1 attenuates bleomycin-induced pulmonary fibrosis in mice. J Exp Med 212: 235-252, 2015.

32. Yogo Y, Fujishima S, Inoue T, Saito F, Shiomi T, Yamaguchi K and Ishizaka A: Macrophage derived chemokine (CCL22), thymus and activation-regulated chemokine (CCL17), and CCR4 in idiopathic pulmonary fibrosis. Respir Res 10: 80, 2009.

33. Wang YC, Liu JS, Tang HK, Nie J, Zhu JX, Wen LL and Guo QL: miR-221 targets HMGA2 to inhibit bleomycin-induced pulmonary fibrosis by regulating TGF $\beta 1 / \mathrm{Smad} 3$-induced EMT. Int J Mol Med 38: 1208-1216, 2016.

34. Zheng Q, Tong M, Ou B, Liu C, Hu C and Yang Y: Isorhamnetin protects against bleomycin-induced pulmonary fibrosis by inhibiting endoplasmic reticulum stress and epithelial-mesenchymal transition. Int J Mol Med 43: 117-126, 2019.

35. Xu X, Wan X, Geng J, Li F, Yang T and Dai H: Rapamycin regulates connective tissue growth factor expression of lung epithelial cells via phosphoinositide 3-kinase. Exp Biol Med (Maywood) 238: 1082-1094, 2013

36. Livak KJ and Schmittgen TD: Analysis of relative gene expression data using real-time quantitative PCR and the 2(-Delta Delta $\mathrm{C}(\mathrm{T})$ ) method. Methods 25: 402-408, 2001

37. Tokhtaeva E, Sachs G and Vagin O: Assembly with the $\mathrm{Na}, \mathrm{K}-\mathrm{ATPase}$ alpha(1) subunit is required for export of beta(1) and beta(2) subunits from the endoplasmic reticulum. Biochemistry 48: 11421-11431, 2009.

38. Lemas MV, Hamrick M, Takeyasu K and Fambrough DM: 26 amino acids of an extracellular domain of the Na,K-ATPase alpha-subunit are sufficient for assembly with the Na,K-ATPase beta-subunit. J Biol Chem 269: 8255-8259, 1994

39. Zatyka M, Ricketts C, da Silva Xavier G, Minton J, Fenton S, Hofmann-Thiel S, Rutter GA and Barrett TG: Sodium-potassium ATPase 1 subunit is a molecular partner of Wolframin, an endoplasmic reticulum protein involved in ER stress. Hum Mol Genet 17: 190-200, 2008.

40. Lawson WE, Crossno PF, Polosukhin VV, Roldan J, Cheng DS, Lane KB, Blackwell TR, Xu C, Markin C, Ware LB, et al: Endoplasmic reticulum stress in alveolar epithelial cells is prominent in IPF: Association with altered surfactant protein processing and herpesvirus infection. Am J Physiol Lung Cell Mol Physiol 294: L1119-L1126, 2008.

41. Mulugeta S, Nguyen V, Russo SJ, Muniswamy M and Beers MF: A surfactant protein $\mathrm{C}$ precursor protein BRICHOS domain mutation causes endoplasmic reticulum stress, proteasome dysfunction, and caspase 3 activation. Am J Respir Cell Mol Biol 32: 521-530, 2005

42. Maguire JA, Mulugeta S and Beers MF: Endoplasmic reticulum stress induced by surfactant protein C BRICHOS mutants promotes proinflammatory signaling by epithelial cells. Am J Respir Cell Mol Biol 44: 404-414, 2011.

43. Ulianich L, Garbi C, Treglia AS, Punzi D, Miele C, Raciti GA, Beguinot F, Consiglio E and Di Jeso B: ER stress is associated with dedifferentiation and an epithelial-to-mesenchymal transition-like phenotype in PC Cl3 thyroid cells. J Cell Sci 121: 477-486, 2008.

44. Morbini P, Inghilleri S, Campo I, Oggionni T, Zorzetto $\mathrm{M}$ and Luisetti M: Incomplete expression of epithelial-mesenchymal transition markers in idiopathic pulmonary fibrosis. Pathol Res Pract 207: 559-567, 2011.

45. La J, Reed E, Chan L, Smolyaninova LV, Akomova OA, Mutlu GM, Orlov SN and Dulin NO: Downregulation of TGF- $\beta$ Receptor-2 Expression and Signaling through Inhibition of $\mathrm{Na} / \mathrm{K}-\mathrm{ATP}$ ase. PLoS One 11: e0168363, 2016.

46. Li B, Huang X, Liu Z, Xu X, Xiao H, Zhang X, Dai H and Wang C: Ouabain ameliorates bleomycin induced pulmonary fibrosis by inhibiting proliferation and promoting apoptosis of lung fibroblasts. Am J Transl Res 10: 2967-2974, 2018. 